\title{
DISTRIBUTION OF CALCIUM-ACTIVATED PROTEASE ACTIVITY AND ENDOGENOUS SUBSTRATES IN THE SQUID NERVOUS SYSTEM $^{1}$
}

\author{
HARISH C. PANT, $,{ }^{\ddagger}, 2$ PAUL E. GALLANT,,${ }^{\ddagger}$, ROBERT GOULD $^{\ddagger}, \|$ AND HAROLD GAINER ${ }^{\ddagger}, \uparrow$ \\ "Laboratory of Preclinical Studies, National Institute on Alcohol Abuse and Alcoholism, Alcohol, Drug Abuse, and Mental \\ Health Administration, Rockville, Maryland 20852; ${ }^{\ddagger}$ Marine Biological Laboratory, Woods Hole, Massachusetts 02543; \\ ${ }^{8}$ Laboratory of Neurobiology, National Institute of Mental Health, Alcohol, Drug Abuse, and Mental Health Administration, \\ Bethesda, Maryland 20205; "Institute for Basic Research in Developmental Disabilities, Staten Island, New York 10314; and \\ "Laboratory of Developmental Neurobiology, National Institute of Child Health and Human Development, National Institutes \\ of Health, Bethesda, Maryland 20205
}

Received February 23, 1982; Revised May 3, 1982; Accepted May 7, 1982

\begin{abstract}
Calcium-activated protease (CAP) activity was studied in various neural tissues of the squid using endogenous (neurofilament protein) and exogenous $\left(\left[{ }^{14} \mathrm{C}\right]\right.$ casein) substrate assays. Both assays demonstrated a significant CAP activity in perikarya from stellate ganglia, in axoplasm extruded from the giant axon, and in squid retinal fibers. The endogenous protein substrates in the perikarya and axons were 60,000 and 200,000 daltons, respectively. The $K_{m}$ for the CAP degradation of $\left[{ }^{14} \mathrm{C}\right]$ casein in axoplasm was about $2 \times 10^{-6} \mathrm{M}$. In contrast, both assays detected no CAP activity nor endogehous substrate in nerve terminals (synaptosomes from squid optic lobe). The absence of both CAP activity and endogenous substrate in nerve endings suggests that the axonal neurofilaments are degraded by CAP at the axon-nerve ending junction, followed by an autoinactivation of the CAP. Consistent with this hypothesis is that exposure of axoplasmic CAP to calcium leads to a rapid degradation of axonal neurofilament protein $\left(t / \frac{1}{2}<2 \mathrm{~min}\right)$ and a slower inactivation of the CAP $\left(t^{1 / 2}\right.$ $=90 \mathrm{~min})$. Axonal CAP requires a relatively high concentration of $\mathrm{Ca}^{2+}(>500 \mu \mathrm{M})$ for activation and, hence, probably is related to the low $\mathrm{Ca}^{2+}$ sensitivity form of CAP found in other tissues.
\end{abstract}

In addition to their well known roles in the regulation of protein turnover in cells (Goldberg and St. John, 1976; Lajtha and Dunlap,. 1981), the actions of intracellular proteases are being increasingly invoked as mechanisms which underlie more selective alterations in cellular structure and function (Reich et al., 1975; Holzer and Heinrich, 1980; Neurath and Walsh, 1976; O'Brien et al., 1978; Baudry and Lynch, 1980). One class of proteases which appears to have sufficient substrate specificity to produce highly selective changes in cells is the calciumactivated proteases (also referred to as calcium-dependent proteases, calcium-activated neutral proteases, and calpain). Although these thiol proteases, with $\mathrm{pH}$ optima around neutrality, are found in a wide variety of tissues

\footnotetext{
'We thank Dr. Rochelle Cohen, Harriet Williams, and Nicholas Bennett for their help in preparing the squid optic lobe synaptosomes, Dr. Walter Troll for gifts of leupeptin and antipain, and Dr. B. Kaminer for trifluoperazine. We also thank Dr. I. Tasaki for his continued interest and support for this work.

${ }^{2}$ To whom correspondence should be addressed at Laboratory of Preclinical Studies, DIR, National Institute on Alcohol Abuse and Alcoholism, 12501 Washington Avenue, Rockville, MD 20852.
}

and cells (Ishiura, 1981; Murachi et al., 1981a, b), their activation in situ often leads to the proteolysis of only one or few specific intracellular proteins, with selective physiological consequences depending on cell type. Calcium-activated proteases have been implicated in specific intracellular enzyme activation (Huston and Krebs, 1968; Nishizuki et al., 1979; Hamon and Bourgoin, 1979), myofibrillar protein turnover (Dayton et al., 1976a, b; Ishiura et al., 1978; Kameyama and Etlinger, 1979), regulation of steroid receptors (Puca et al., 1977; Vedeckis et al., 1980) and glutamate receptors (Baudry and Lynch, 1980; Baudry et al., 1981), and modification of cytoskeletal proteins (Anderson et al., 1977; Phillips and Jakabova, 1977; Triplett et al., 1972; Wallach et al., 1978; Gilbert et al., 1975; Lucas et al., 1979).

The presence of calcium-activated proteases (CAPs) in nervous tissue was reported initially by Guroff (1964). The first indication, however, that the CAP was indeed of neuronal origin and had a specific endogenous protein substrate came from the work of Gilbert and his colleagues on axoplasm isolated from the giant axons of the fan worm, Myxicola, and the squid, Loligo (Gilbert, 1975; 
Gilbert et al., 1975; Anderton et al., 1976). This and subsequent work on both invertebrate and vertebrate axons showed that the CAP was a neutral, thiol protease specifically activated by $\mathrm{Ca}^{2+}$ which selectively degraded neurofilament proteins (Gilbert et al., 1975; Schlaepfer and Micko, 1978; Schlaepfer and Freeman, 1980; Pant et al., 1979a; Pant and Gainer, 1980; Schlaepfer et al., 1981; Eagles et al., 1981).

The physiological role of the CAP in axons is less well understood. One proposal is that the destruction of neurofilaments preceding nerve degeneration (after injury) is mediated by CAP (Schlaepfer, 1974; Schlaepfer and Micko, 1978). Another proposal (Lasek and Hoffman, 1976) suggests that the turnover of neurofilaments in nerve terminals may involve the CAP and that one mechanism regulating the growth of axons might be the action of CAP in the developing nerve terminals (Lasek and Black, 1977). One apparent difficulty for the latter proposal is that the axonal CAP directed at neurofilament degradation requires an unphysiological level $(>500$ $\mu \mathrm{M})$ of calcium ion for activation (Pant and Gainer, 1980). Even in the synaptic terminal, where, during activity, the $\mathrm{Ca}^{2+}$ influx is relatively high, the internal calcium concentration rarely exceeds $10 \mu \mathrm{M}$ (Llinas and Heuser, 1977). One possibility is that, when the axonal CAP enters the nerve terminal, its $\mathrm{Ca}^{2+}$ dependency shifts to lower level requirements for activation. 'Therefore, in this paper, we attempt to compare the properties of CAP in the three principal neuronal sites: perikaryon, axon, and nerve terminal.

\section{Materials and Methods}

All experiments were performed on freshly prepared tissues from squid (Loligo pealii) obtained at the Marine Biological Laboratory, Woods Hole, MA. The animals were maintained for 2 to $16 \mathrm{hr}$ before use in laboratory tanks containing running sea water. Dissection of the dorsal giant nerve fibers was performed under running sea water on a dissecting table illuminated from below through a glass window. Axoplasm was extruded from the dissected intact axon in the conventional manner to avoid contamination of the axoplasm by sea water and external tissues. Extruded axoplasm was transferred quickly into 1.2-ml Eppendorf tubes (catalog No. 2266 411-11-1 from Brinkmann Instruments) on ice containing $20 \mathrm{~mm}$ Tris- $\mathrm{HCl}, \mathrm{pH} 7.5$, and homogenized into a uniform suspension. Aliquots of this uniform suspension were used in most of the experiments. In some cases, extruded axoplasm was suspended in artificial axoplasm solution (Rubinson and Baker, 1979). This suspension was centrifuged for $1 \mathrm{~min}$ at $10,000 \mathrm{rpm}$ in a Beckman centrifuge and the pellet was homogenized in $20 \mathrm{~mm}$ Tris- $\mathrm{HCl}, \mathrm{pH}$ 7.5 , buffer solution.

The ganglion cells (perikarya in stellate ganglia) and retinal fibers were dissected, washed in isomolar sucrose, and transferred into glass homogenizers containing 20 $\mathrm{mm}$ Tris-HCl ( $\mathrm{pH}$ 7.5) buffer solution on ice. These samples were homogenized to uniform suspension. Aliquots of these suspensions were used in experiments as described below.

Synaptosomes were prepared as described by Dowdell and Whittaker (1973) and Dowdell and Simon (1973) with minor modifications. Briefly, optic lobes from squid were homogenized as a $20 \%(\mathrm{w} / \mathrm{v})$ solution in $1 \mathrm{~m}$ sucrose by six complete strokes of a glass-on-glass Ten-Broek Homogenizer (B pestle). The homogenate then was centrifuged at $10,000 \mathrm{rpm}(13,000 \times \mathrm{g})$ for $1 \mathrm{hr}$ at $4^{\circ} \mathrm{C}$ on a Sorvall RC2B preparative centrifuge. The synaptosomal pellicle then was recovered by aspiration and dispersed in a minimal volume of $1 \mathrm{M}$ sucrose, and aliquots of this preparation were homogenized in $20 \mathrm{~mm}$ Tris- $\mathrm{HCl}, \mathrm{pH}$ 7.5 , for further use in the degradation experiments described below.

Assay of calcium-activated protease (CAP) activity in squid axoplasm using an endogenous substrate $\left(N F_{200}\right)$. CAP activity in axoplasm was measured using a previously described assay (Pant and Gainer, 1980) based on the selective degradation of an endogenous substrate $\left(200,000\right.$-dalton neurofilament protein or $\left.\mathrm{NF}_{200}\right)$. Briefly, equal aliquots $(20 \mu \mathrm{l})$ of the above axoplasm solution were transferred to tubes containing $80 \mu \mathrm{l}$ of an appropriate buffer at a given $\mathrm{pH}$ and divalent cation concentration (see text). In all experiments, control tubes containing buffer with no divalent cations and $5 \mathrm{~mm}$ EGTA were used. Thus, each of the tubes contained an identical amount of axoplasmic protein at the outset of the incubation period in $100 \mu \mathrm{l}$ of solution. The samples were stirred briefly and incubated for $30 \mathrm{~min}$ at $22 \pm 1^{\circ} \mathrm{C}$. The incubation was terminated by adding trichloroacetic acid (TCA) to the incubation mixture to a concentration of $10 \%$, and the resultant TCA pellet, obtained after centrifugation, was washed twice with ethanol:ether (1:1, $\mathrm{w}: \mathrm{v})$ and then with ether to remove the TCA. The dried pellet then was solubilized in $2.5 \% \mathrm{Na}_{2} \mathrm{CO}_{3}$ and $2 \%$ SDS and reduced with $2-\beta$-mercaptoethanol. SDS-gel electrophoresis of the samples was performed on $5 \%$ polyacrylamide gels according to the method described by Neville (1971). Following electrophoresis, the gels were stained with either Coomassie Brilliant Blue or Fast Green, destained, and scanned at $560 \mathrm{~nm}$ (or $630 \mathrm{~nm}$ for Fast Green) using a Beckman model 25 gel scanner. The scanning patterns were evaluated by standard quantitative densitometric techniques (Gorovsky et al., 1970; Bertolini et al., 1976). Identical data were obtained when either Coomassie Brilliant Blue or Fast Green was used as the stain. These densitometric patterns are highly reproducible (Pant et al., 1979a; Pant and Gainer, 1980) and the measurements of $\mathrm{NF}_{200}$ degradation, under various experimental conditions, were made in this manner.

Assay of $\mathrm{Ca}^{2+}$-activated proteolytic activity using [methyl ${ }^{14} \mathrm{C}$ ]casein as substrate. Proteolytic activity in the various tissue preparations were determined by measuring the hydrolysis of $\left[\right.$ methyl $\left.-{ }^{14} \mathrm{C}\right]$ casein by tissue samples to trichloroacetic acid-soluble peptides. Each assay tube (assays were performed in duplicate or triplicate) contained an aliquot of the appropriate tissue sample, $2.53 \mu \mathrm{g}$ of $\left[\right.$ methyl. $\left.{ }^{14} \mathrm{C}\right]$ casein (New England Nuclear Corp.; specific activity, $0.0019 \mathrm{mCi} / \mathrm{mg}$ ), in a total volume of $150 \mu \mathrm{l}$. The standard incubation was in $20 \mathrm{~mm}$ Tris$\mathrm{HCl}$ buffer (pH 7.5) for $30 \mathrm{~min}$ at $23^{\circ} \mathrm{C}$. Various additions to the incubation medium are described in the text. Each incubation series also contained control assay tubes in which heat-inactivated tissue (or no tissue sample) was added. Each assay also contained samples with $0 \mathrm{mM}$ 
$\mathrm{Ca}^{2+}$ and $5 \mathrm{~mm}$ EGTA for the measurement of background protease activity in the tissue sample. This value was subtracted from the proteolytic activity measured in the presence of $\mathrm{Ca}^{2+}$ to give specifically $\mathrm{Ca}^{2+}$-induced proteolytic activity. The incubations were terminated by addition of $150 \mu \mathrm{l}$ of $20 \%$ trichloroacelic acid, and $10 \mu \mathrm{l}$ (1 $\mathrm{mg}$ of protein $/ \mathrm{ml}$ ) of squid brain synaptosomes were added as carrier proteins. After 2 to $3 \mathrm{hr}$ at $4^{\circ} \mathrm{C}$, the samples were centrifuged at $10,000 \mathrm{rpm}$ for $20 \mathrm{~min}$ in a Beckman Microfuge. One hundred fifty microliters of each supernatant containing TCA-soluble peptides was mixed with $150 \mu \mathrm{l}$ of $0.1 \mathrm{~N} \mathrm{NaOH}$ and $10 \mathrm{ml}$ of Aquasol in glass counting vials. The vials were counted using a Beckman liquid scintillation counter after $15 \mathrm{hr}$ in the dark in order to eliminate chemiluminescence.

Total protein in the tissue samples (homogenates) was measured by the method of Bradford (1976) using premixed reagents purchased from Bio-Rad Laboratories. Bovine serum albumin was used as a standard in the protein assays.

Calculations of CAP activity. In the $\left[{ }^{14} \mathrm{C}\right]$ casein assays, the amount of casein degraded was determined from the radioactivity in the TCA-soluble peptides and the specific activity of the $\left[{ }^{14} \mathrm{C}\right]$ casein substrate. CAP activity was calculated as micrograms of casein degraded in the presence of $\mathrm{Ca}^{2+}$ minus micrograms of casein degraded in absence of $\mathrm{Ca}^{2+}$ (expressed as micrograms of casein degraded per $\mathrm{mg}$ of tissue protein per 30 -min incubation). CAP activity using $\mathrm{NF}_{200}$ degradation was calculated similarly using micrograms of $\mathrm{NF}_{200}$ degraded values obtained from quantitative densitometry as described above (in this case, the quantity of $\mathrm{NF}_{200}$ (in axoplasm) incubated in the absence of $\mathrm{Ca}^{2+}(0 \mathrm{mM})+5 \mathrm{~mm}$ EGTA was taken as the initial substrate value). The data also are expressed as the percentage of substrate degraded (e.g., Figs. 1, 2A, and 4), with the maximum degradation under the specific experimental condition equal to $100 \%$.

The rate constants $(K)$ in Figure $2 B$ were calculated assuming first order reaction kinetics, $K=(2.3 \log s /(s$ $-x)) / t$, where $s$ is the amount of substrate (in micrograms) in the initial condition, and $x$ is the amount of substrate (in micrograms) degraded over the time ( $t$, in minutes) of incubation.

Each assay was performed in triplicate, with a $<7 \%$ variation in the value of replicates. Average values of these triplicate assays were used in the calculations.

Polyacrylamide gel electrophoretic (PAGE) analysis of endogenous substrates. Tissue samples were incubated and treated as described above for analysis of $\mathrm{NF}_{200}$ degradation by axoplasm. The proteins in these samples then were separated by PAGE in SDS using 7 to $11 \%$ gradient slab gels. The gels were stained by Coomassie Blue, destained, and photographed.

Chemicals and reagents. $\left[\right.$ methyl $\left.-{ }^{14} \mathrm{C}\right]$ Casein was purchased from New England Nuclear Corp. The protease inhibitors luepeptin and antipain were obtained from Dr. Walter Troll (New York University). Trifluoperazine was obtained from Dr. Benjamin Kaminer (Boston University). Calmodulin was obtained from Calbiochem. All other chemicals were of the highest grade commercially available. All solutions were freshly prepared in deionized, double distilled water.

\section{Results}

Comparisons of CAP activity measured in axoplasm by an endogenous $\left(N F_{200}\right.$ ) and exogenous ([methyl $\left.{ }^{14} \mathrm{C}\right]$ casein) substrate assay. In a previous study (Pant et al., $1979 \mathrm{~b}$ ), we found that squid synaptosomes did not contain sufficient neurofilament protein to allow for an endogenous substrate assay of CAP. Therefore, it was necessary to use an alternative exogenous substrate assay. However, before doing so, we felt that it was necessary to compare the two assays using extruded axoplasm. Figure 1 illustrates the $\mathrm{Ca}^{2+}$ dependency of degradation of each of these substrates by axoplasmic CAP. Virtually all of the $\mathrm{NF}_{200}$ protein substrate is degraded in the presence of $10 \mathrm{mM} \mathrm{Ca}{ }^{2+}$ in $30 \mathrm{~min}$ and the data were expressed as a percentage of maximum CAP activity (i.e., CAP activity at $10 \mathrm{mM} \mathrm{Ca}{ }^{2+}$; see "Materials and Methods"). A relatively high $\mathrm{Ca}^{2+}$ concentration $(>0.5$ $\mathrm{mM}$ ) is necessary to initiate CAP activity in squid axoplasm (Fig. 1; see Pant and Gainer, 1980). While this is the case for both substrate assays, the $\mathrm{NF}_{200}$ substrate appears to reach maximum degradation at lower calcium levels $(<4 \mathrm{~mm})$ than the casein substrate ( 5 to $10 \mathrm{~mm})$.

This difference is due, in part, to the different kinetics of degradation of these two substrates. Figure $2 A$ illustrates the time courses of degradation of the endogenous $\mathrm{NF}_{200}$ protein and exogenous $\left[{ }^{14} \mathrm{C}\right]$ casein by axoplasmic CAP (in the presence of $10 \mathrm{~mm} \mathrm{Ca}^{2+}$ ). Both substrates are degraded completely after $30 \mathrm{~min}$ of incubation; however, the $\mathrm{NF}_{200}$ is degraded more rapidly than the $\left[{ }^{14} \mathrm{C}\right]$ casein substrate (Fig. $2 A$ ). Further kinetic analysis of these data, assuming first order reaction kinetics, is illustrated in Figure $2 B$ (see "Materials and Methods"). $\mathrm{NF}_{200}$ degradation is characterized by two rate constants $(K)$, a faster rate $\left(K=3.4 \mathrm{~min}^{-1}\right)$ and a slower one $(K$ $=1.2 \mathrm{~min}^{-1}$ ), with the latter being comparable to the single rate constant $\left(K=0.9 \mathrm{~min}^{-1}\right)$ found for casein degradation by axoplasmic CAP. These data suggest that the endogenous $\mathrm{NF}_{200}$ protein substrate in the axoplasm homogenate may exist in two different forms with respect to the axoplasmic CAP: one form which behaves similarly in its degradation kinetics to exogenous casein and another which is degraded more rapidly (see "Discussion").

Figure 3 illustrates a Lineweaver-Burk (double reciprocal) plot of CAP activity in axoplasm containing $10 \mathrm{~mm}$ $\mathrm{Ca}^{2+}$ at various concentrations of the $\left[{ }^{14} \mathrm{C}\right]$ casein substrate. The $K_{m}$ was found to be $2.03 \times 10^{-6} \mathrm{M}$, a value similar to that found for calcium-activated proteases in other tissues (Puca et al., 1977).

The above data indicule that the $\left[{ }^{14} \mathrm{C}\right]$ casein degradation assay for CAP activity provides an effective alternative to the use of the more tedious endogenous substrate degradation assay. The most important point is that this exogenous substrate assay allows a determination of CAP activity independent of the presence or absence of an endogenous substrate in the tissue. Further evidence that the endogenous $\mathrm{NF}_{200}$ and exogenous casein are being degraded by the same CAP activity comes from protease inhibitor studies. In a previous report (Pant and Gainer, 1980), we showed that iodoacetic acid (1 $\mathrm{mM}), p$-chloromercuribenzoate $(1 \mathrm{~mm})$, and 7-aminochloro-3-tosylamidoheptane completely inhibited the 


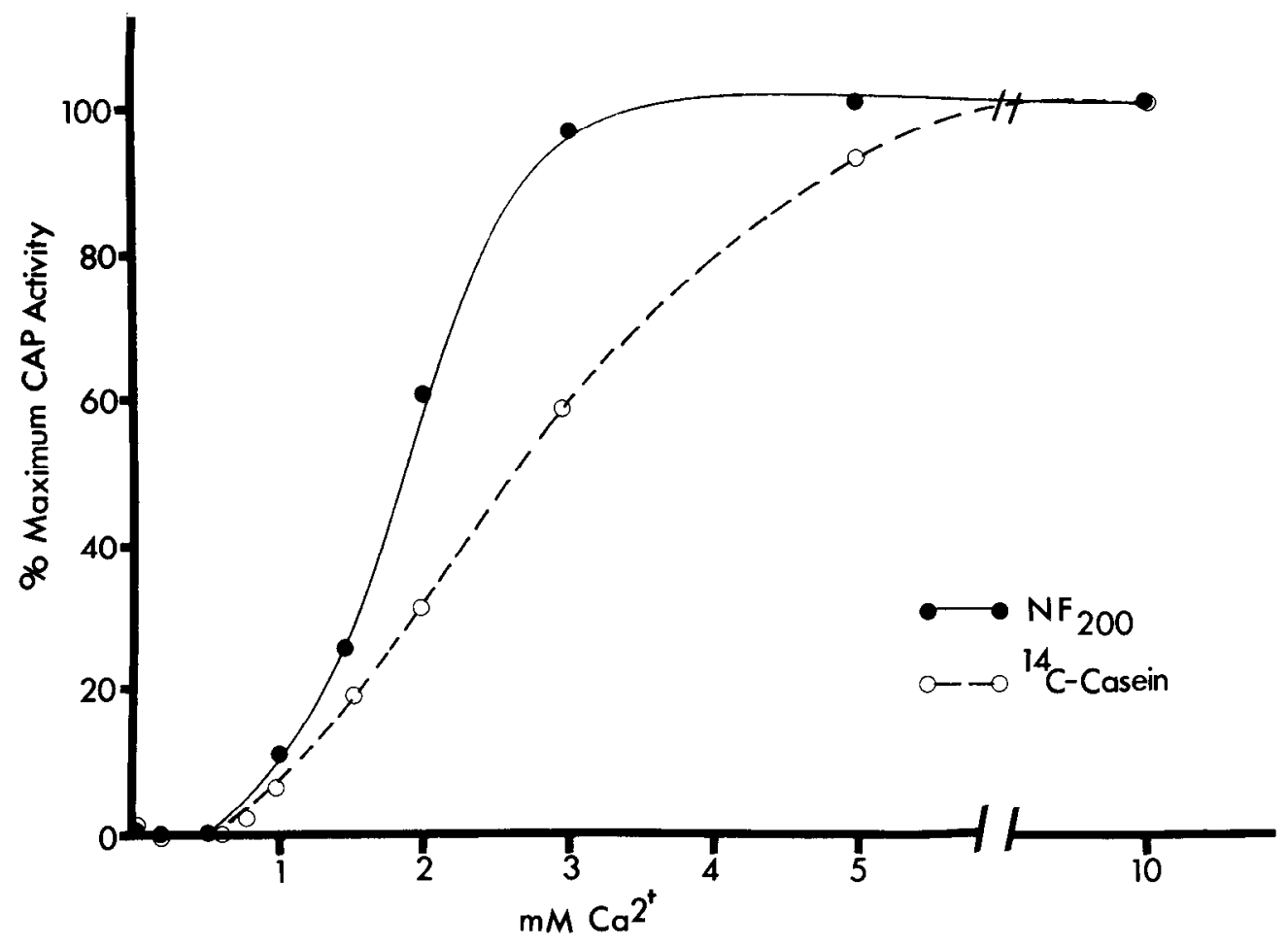

Figure 1. Comparison of the calcium-activated protease (CAP) activity in extruded axoplasm using an endogenous protein substrate (axoplasm neurofilament protein, $\mathrm{NF}_{200}$ ) versus an exogenous substrate $\left(\left[\right.\right.$ methyl- $\left.{ }^{14} \mathrm{C}\right]$ casein) assay (see "Materials and Methods"). The CAP activity is expressed on the ordinate as a percentage of the maximal value obtained in the specific assay (i.e., at $10 \mathrm{mM} \mathrm{Ca}^{2+}$ ).

degradation of $\mathrm{NF}_{200}$ protein in axoplasm by CAP. Furthermore, $1 \mathrm{~mm}$ leupeptin ((acetyl)-L-leucyl-1-leucyl-1argininal), a nontoxic protease inhibitor (Libby and Goldberg, 1978; Stracher et al., 1978) which inhibits plasmin, trypsin, kallikrein, thrombokinase, papain, and cathepsin $\mathrm{B}$ but not chymotrypsin or elastase (Umezawa and Aoyagi, 1977), also completely blocked the degradation of $\mathrm{NF}_{200}$ protein (Pant and Gainer, 1980). The degradation of $\left[{ }^{14} \mathrm{C}\right]$ casein by $\mathrm{Ca}^{2+}$-induced proteolysis in axoplasm was blocked by a similar spectrum of protease inhibitors and by $1 \mathrm{~mm}$ leupeptin or $1 \mathrm{~mm}$ antipain (data not shown).

Distribution of CAP activity in various neural tissues of the squid. Homogenates of squid axoplasm, stellate ganglion perikarya, retinal fibers, and synaptosomes derived from the optic lobe were incubated with $\left[{ }^{14} \mathrm{C}\right]$ casein in the presence (or absence) of $10 \mathrm{mM} \mathrm{Ca}^{2+}$ for $30 \mathrm{~min}$ at $23^{\circ} \mathrm{C}$ under standard conditions (see "Materials and Methods"). The results of these experiments are shown in Table $I$ where the protease activity is expressed as micrograms of $\left[{ }^{14} \mathrm{C}\right]$ casein degraded per $\mathrm{mg}$ of tissue protein per 30 min of incubation. The CAP activity was determined by subtracting the proteolytic activity in each tissue in the absence of $\mathrm{Ca}^{2+}\left(0 \mathrm{mM} \mathrm{Ca}{ }^{2+}, 5 \mathrm{mM}\right.$ EGTA) from the proteolytic activity measured in the presence of $10 \mathrm{mM} \mathrm{Ca}{ }^{2+}$. As can be seen in Table I, extruded axoplasm had the greatest CAP activity, about 3.6 -fold greater than ganglion cells and 20.7 -fold greater than squid retinal fibers. It is difficult to evaluate the exact significance of these differences in CAP activity since only the extruded axoplasm represents a pure neural component. The ganglion cells and, to a greater extent, the retinal fibers are contaminated by surrounding glial cells which may not contain significant CAP activity but which would contribute to the protein measurement used in the calculation of the CAP activity of the tissue sample. In any case, the most significant data in Table I are that the synaptosomes were completely devoid of CAP activity. We were somewhat surprised by this data since we had anticipated, based upon the hypothesis that the rapid turnover of neurofilaments in nerve terminals was due to the action of CAP (Lasek and Hoffman, 1976), that the CAP activity in the synaptosome preparation would be substantial. Furthermore, this was surprising since the cellular structure immediately continuous with the nerve terminal, the axon (represented by axoplasm and retinal fibers in our assay), contained a large amount of CAP activity. Since proteins in nerve terminals normally are derived from axons via axonal transport processes, the lack of CAP activity in the nerve terminal could reflect either: (1) a relatively rapid turnover of CAP in the terminal or (2) the accumulation of a specific inhibitor of CAP in the terminal. Both of these possibilities are feasible since CAPs in other systems have been reported to undergo autolysis after $\mathrm{Ca}^{2+}$ activation (Gilbert et al., 1975; Puca et al., 1977), and endogenous inhibitors of CAP also have reported (Murachi et al., 1981a, b). Experimental data pertinent to these alternative possibilities are presented below.

Inactivation of axoplasmic CAP by calcium. Figure 4 shows the results of experiments in which axoplasm was preincubated in the absence (open circles) or presence (solid circles) of $10 \mathrm{mM} \mathrm{Ca}^{2+}$ for various times and then 

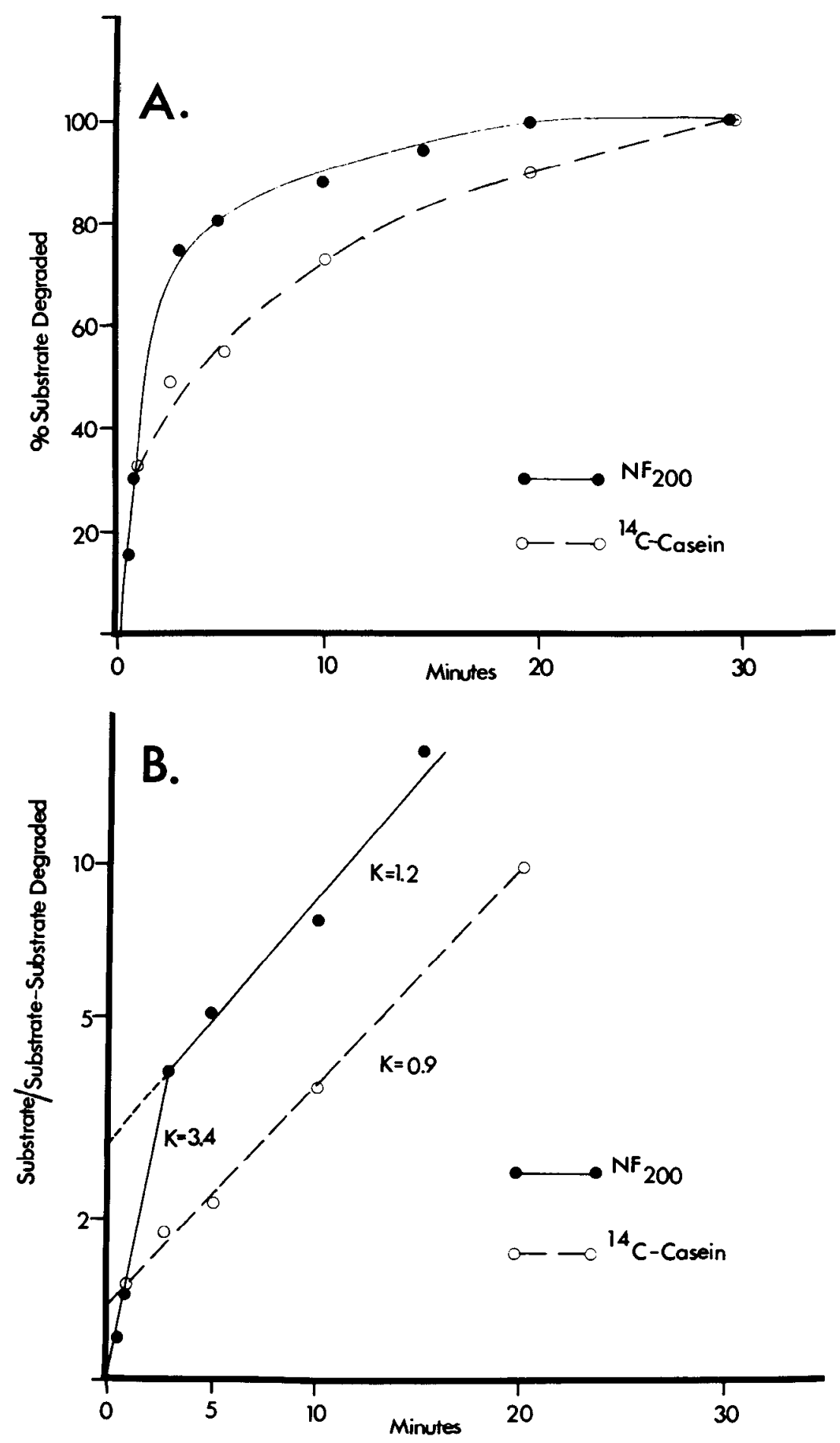

Figure 2. Comparison of the degradation rates of an endogenous substrate $\left(\mathrm{NF}_{200}\right)$ and an exogenous substrate $\left(\left[\mathrm{methyl}{ }^{14} \mathrm{C}\right]\right.$ casein) by axoplasmic CAP (in $10 \mathrm{mM} \mathrm{Ca}^{2+}$ ). $A$, Time course of substrate degradation by CAP; $B$, evaluation of the rate constant of degradation of each substrate by CAP, assuming first order kinetics. The rate constant $(K)$ was calculated as described under "Materials and Methods." Note that the endogenous substrate degradation was characterized by two rate constants (3.4/min and $1.2 / \mathrm{min})$, whereas the exogenous casein substrate was degraded only at the lower rate $(0.9 / \mathrm{min})$.

assayed for CAP activity by the $\left[{ }^{14} \mathrm{C}\right]$ casein method. As can be seen in Figure 4, preincubation of axoplasm for as long as $22 \mathrm{hr}$ (at $23^{\circ} \mathrm{C}$ ) in the absence of $\mathrm{Ca}^{2+}$ did not affect its CAP activity. In contrast, preincubation of axoplasm in $10 \mathrm{mM} \mathrm{Ca}{ }^{2+}$ produced a slow decrease in CAP activity (half-time of reduction of CAP activity, about $90 \mathrm{~min}$ ) so that, after about $6 \mathrm{hr}$ of preincubation, virtually no CAP activity could be detected in the axoplasm. The time course of the endogenous $\mathrm{NF}_{200}$ protein degradation by CAP (data shown in Fig. $2 A$ ) under these conditions also is plotted in Figure 4 (dashed line) for comparison (half-time, about $2 \mathrm{~min}$ ). These data are 


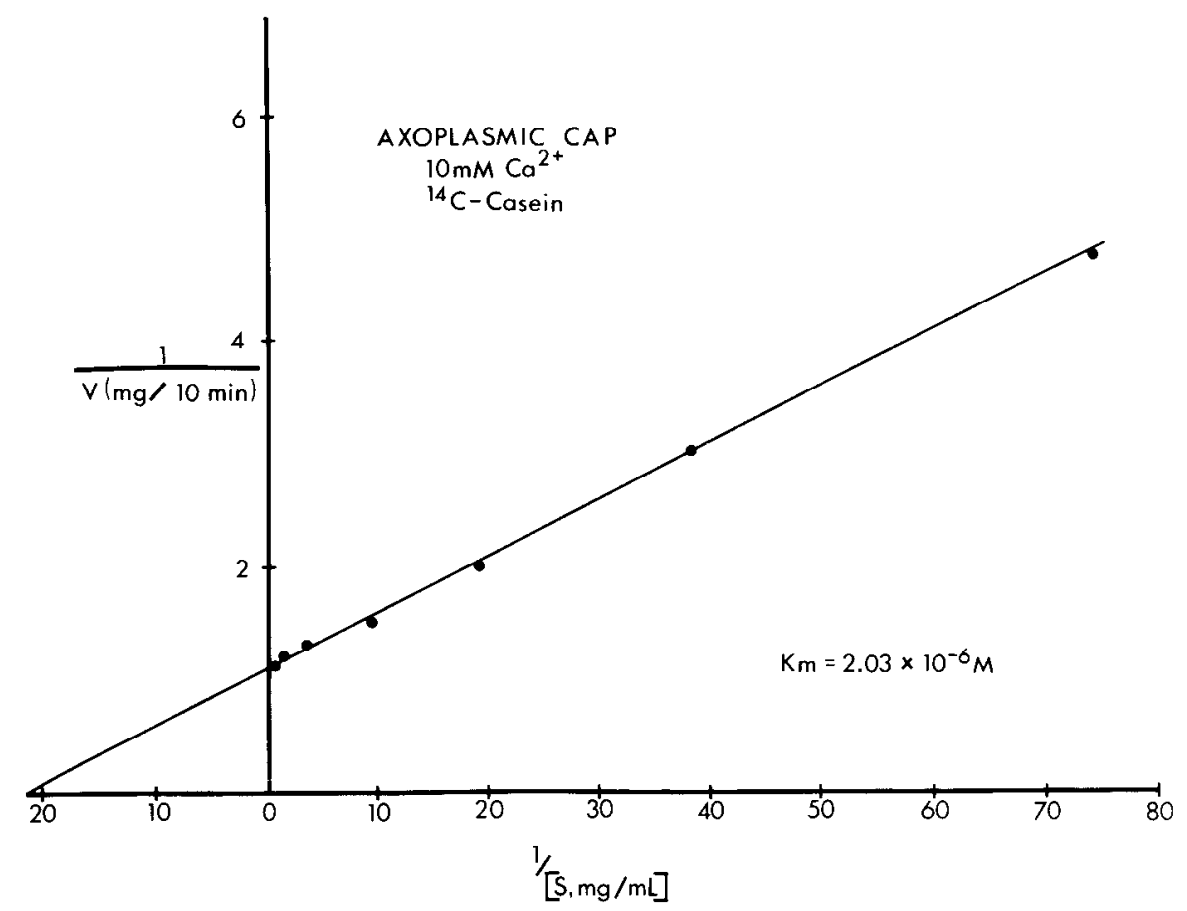

Figure 3. Lineweaver-Burk plot of axoplasmic CAP degradation of $\left[\right.$ methyl $\left.{ }^{14} \mathrm{C}\right]$ casein at $10 \mathrm{mM} \mathrm{Ca}{ }^{2+}$. The $K_{m}$ of the reaction was calculated to be $2.03 \times 10^{-6} \mathrm{M}$.

consistent with the notion that, following activation of CAP by $\mathrm{Ca}^{2+}$ in the nerve terminals, the endogenous protein substrate (e.g., $\mathrm{NF}_{200}$ ) is degraded rapidly, followed by a slower inactivation of CAP. Given this scenario, neither axoplasmic CAP nor endogenous substrate would be expected to accumulate in the terminals.

Distribution of endogenous protein substrates in various neural tissues of the squid. Figure 5 shows the Coomassie Blue-stained gel patterns of proteins from ganglion cells, extruded axoplasm, retinal fibers, and synaptosomes after incubation for $30 \mathrm{~min}$ in the presence and absence of $10 \mathrm{~mm} \mathrm{Ca}^{2+}$. The arrows in Figure 5 point to proteins which are clearly present in the tissue after incubation in the absence of $\mathrm{Ca}^{2+}$ but are either greatly reduced or completely missing after incubation with 10 $\mathrm{mM} \mathrm{Ca}{ }^{2+}$. Each of the tissues which contained CAP activity, as measured by the casein assay (Table I), also contained at least one endogenous substrate candidate (Fig. 5). The synaptosomes which contain no measurable CAP (Table I) also appear to have no endogenous substrate (Fig. 5). Note that the synaptosomes did not contain the 200,000-dalton neurofilament protein which was found to be the major endogenous substrate in axons (i.e., in axoplasm and retinal fibers). Although the ganglion cells contained an endogenous substrate, it was not 200,000 daltons but rather around 60,000 daltons. In this regard, it is interesting that the major polypeptide found in preparations of purified squid brain intermediate filaments (neurofilaments) was 60,000 daltons (Zackroff and Goldman, 1980). Whether the 60,000-dalton substrate in the ganglion cells (Fig. 5) is related to this neurofilament protein remains to be determined.

If the synaptosome does not contain CAP activity (Table I), then the failure to find an endogenous substrate in the experiment depicted in Figure 5 cannot be
TABLE I

Effects of $\mathrm{Ca}^{2+}$ on protease activity in squid neural tissues

These results were determined by the degradation of $\left[{ }^{14} \mathrm{C}\right]$ casein (nominal specific activity, $0.0019 \mathrm{mCi} / \mathrm{mg}$; from New England Nuclear, Boston, lot 1309-221) to TCA-soluble peptides. The incubation of tissues was in $150 \mu \mathrm{l}$ of $20 \mathrm{mM}$ Tris-HCl (pH 7.5) containing $2.53 \mu \mathrm{g}$ of $\left[{ }^{14} \mathrm{C}\right]$ casein for $30 \mathrm{~min}$. Each incubation mixture contained about 9,500 cpm of $\left[{ }^{14} \mathrm{C}\right]$ casein and between 10 and $100 \mu \mathrm{g}$ of tissue protein. The data in the table represent average values of $14,6,4$, and 8 independent measurements of axoplasm, ganglion cells, retinal fibers, and synaptosomes, respectively. The variations in the values were less than $10 \%$ of the means, and the detection limit in the experiments was $<0.01 \mu \mathrm{g}$ of $\left[{ }^{14} \mathrm{C}\right]$ casein degraded.

\begin{tabular}{|c|c|c|c|}
\hline \multirow[b]{2}{*}{ Tissue } & \multicolumn{3}{|c|}{ Protease Activity } \\
\hline & $\begin{array}{c}0 \mathrm{mM} \mathrm{Ca}^{2+} \\
(5 \mathrm{mM} \text { EGTA })\end{array}$ & $10 \mathrm{mM} \mathrm{Ca}^{2+}$ & $\begin{array}{c}\text { CAP } \\
\text { Activity }^{a}\end{array}$ \\
\hline & $\mu \mathrm{g}\left[{ }^{14} \mathrm{C}\right]$ casein $\mathrm{d}$ & $\begin{array}{l}\mathrm{raded} / \mathrm{mg} \text { tissue } \\
\min \end{array}$ & protein $/ 30$ \\
\hline Axoplasm (giant axon) & 0.45 & 97.1 & 96.7 \\
\hline $\begin{array}{l}\text { Ganglion cells (perikarya } \\
\text { from stellate ganglion) }\end{array}$ & 0.3 & 29.1 & 28.8 \\
\hline Retinal fibers & 0.14 & 4.8 & 4.7 \\
\hline Synaptosomes (optic lobe) & 0.02 & 0.02 & 0 \\
\hline
\end{tabular}

${ }^{a}$ CAP activity, protease activity in $10 \mathrm{mM} \mathrm{Ca}^{2+}-$ protease activity in $0 \mathrm{mM} \mathrm{Ca}^{2+}$

taken as evidence that such a substrate does not exist in the synaptosome preparation. Figure 6 represents an attempt to address this issue more directly. In this experiment, axoplasm and synaptosome homogenates were incubated separately or together (after mixing) in the presence of $10 \mathrm{mM} \mathrm{Ca}^{2+}$. The SDS-gel protein patterns resulting from these incubations are shown in Figure 6. There were no significant differences in the gel patterns irrespective of whether the axoplasm and synaptosome homogenate preparations were mixed before or after the 


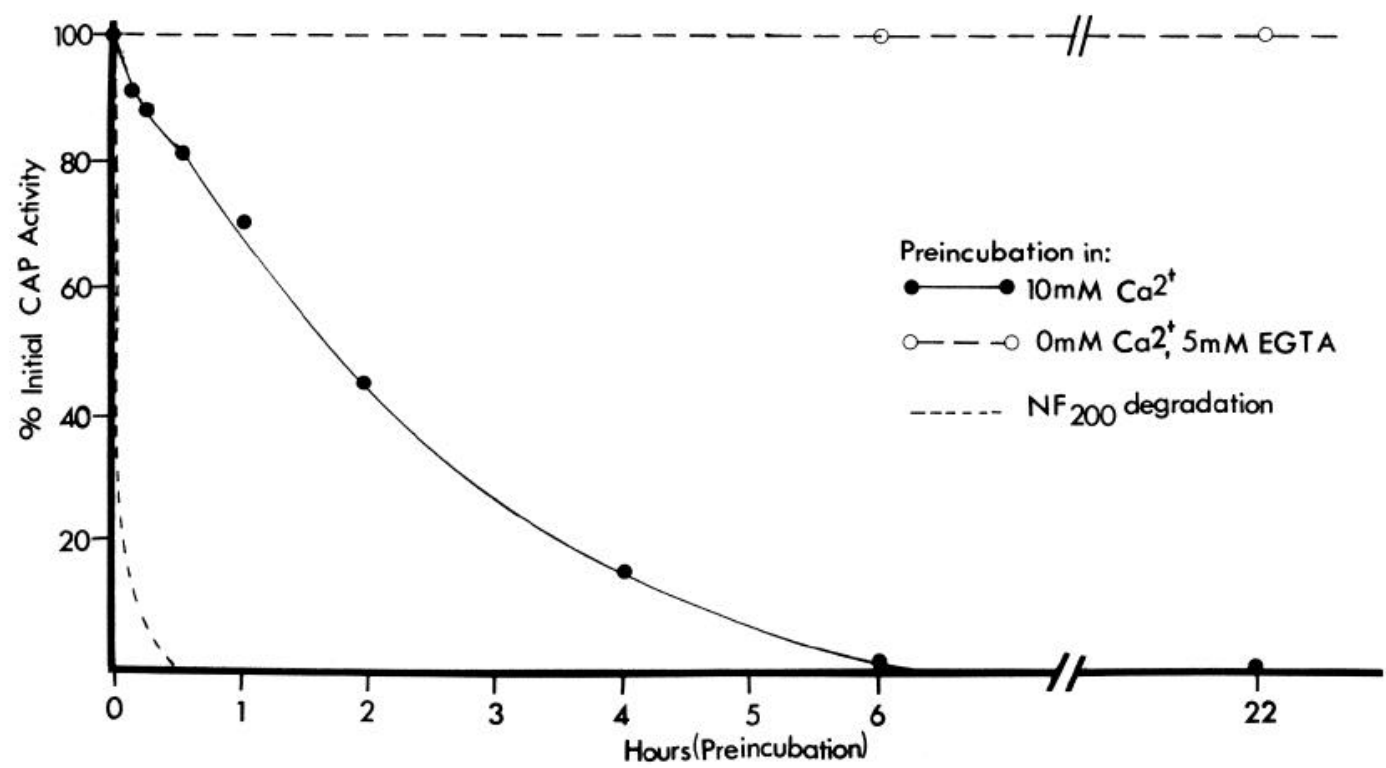

Figure 4. Inactivation of axoplasmic CAP by $\mathrm{Ca}^{2+}$. Equal aliquots of axoplasm suspended in $20 \mathrm{~mm}$ Tris- $\mathrm{HCl}$, pH 7.5 , were preincubated for various times in the presence of $10 \mathrm{mM} \mathrm{Ca}^{2+}(\odot)$ or $0 \mathrm{mM} \mathrm{Ca}^{2+}+5 \mathrm{~mm}$ EGTA (O). Equal amounts of [methyl${ }^{14} \mathrm{C}$ ]casein were subsequently added to the preincubated samples and the samples were incubated further for 30 min. The reaction was terminated by adding TCA ( $10 \%$ final concentration), and their CAP activities were measured as described under "Materials and Methods." The time course of endogenous $\mathrm{NF}_{200}$ degradation (see Fig. $2 A$ ) also is illustrated (dashed line) for comparison.

\section{Ganglion Cells}

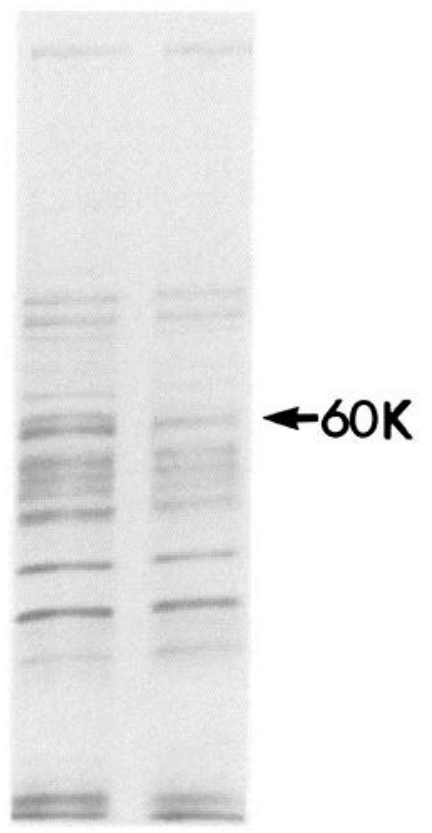

$-\mathrm{Ca}^{+}+\mathrm{Ca}^{+}$
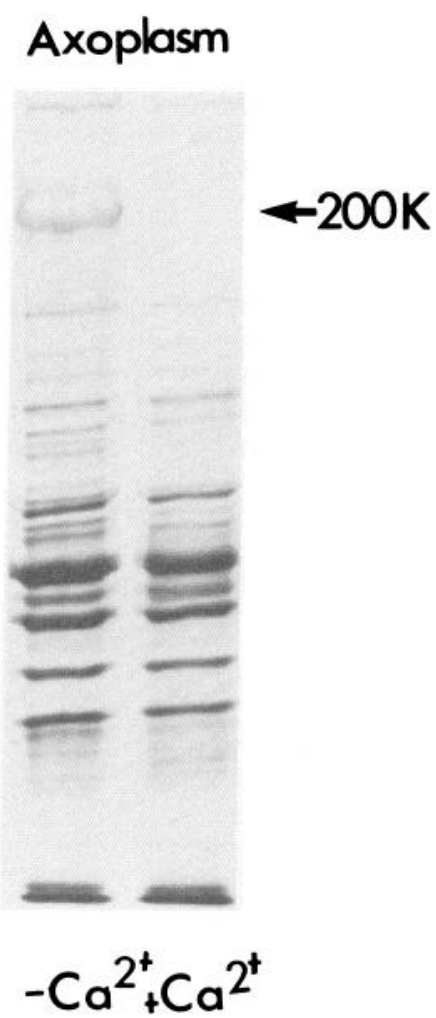

Synaptosomes
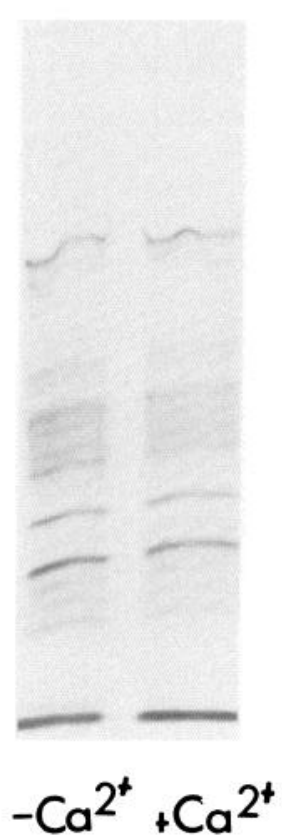

\section{Retinal fibers}

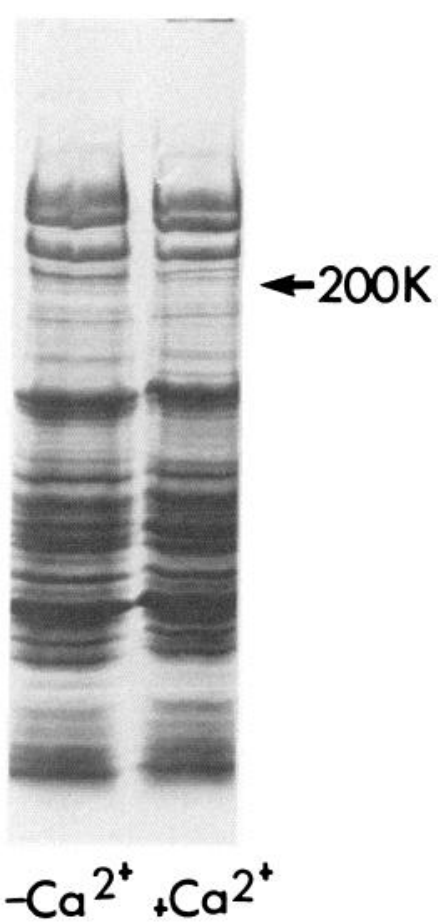

Figure 5. Evaluation of endogenous protein substrates degraded by endogenous CAP in various neural tissues in the squid. Homogenates of axoplasm (giant axon), ganglion cells (stellate ganglion), retinal fibers, and synaptosomes (optic lobe) were incubated in the presence $\left(+\mathrm{Ca}^{2+}\right)$ and absence $\left(-\mathrm{Ca}^{2+}\right)$ of calcium (see "Materials and Methods"). The reaction was terminated by the addition of $10 \%$ SDS, and the proteins in the incubates were analyzed by SDS-gradient PAGE. The arrows point to the endogenous proteins degraded by the CAP in each tissue.

incubation with $\mathrm{Ca}^{2+}$ (compare columns $C$ and $D$ in Fig. 6). This indicates that the presence of axoplasmic CAP during the incubation did not cause the degradation of any specific protein in the synaptosome preparation.
Similar experiments using ganglion-derived CAP and synaptosomes were done with similar results (H. C. Pant, P. E. Gallant, R. Gould, and H. Gainer, unpublished data). These data are consistent with the interpretation 

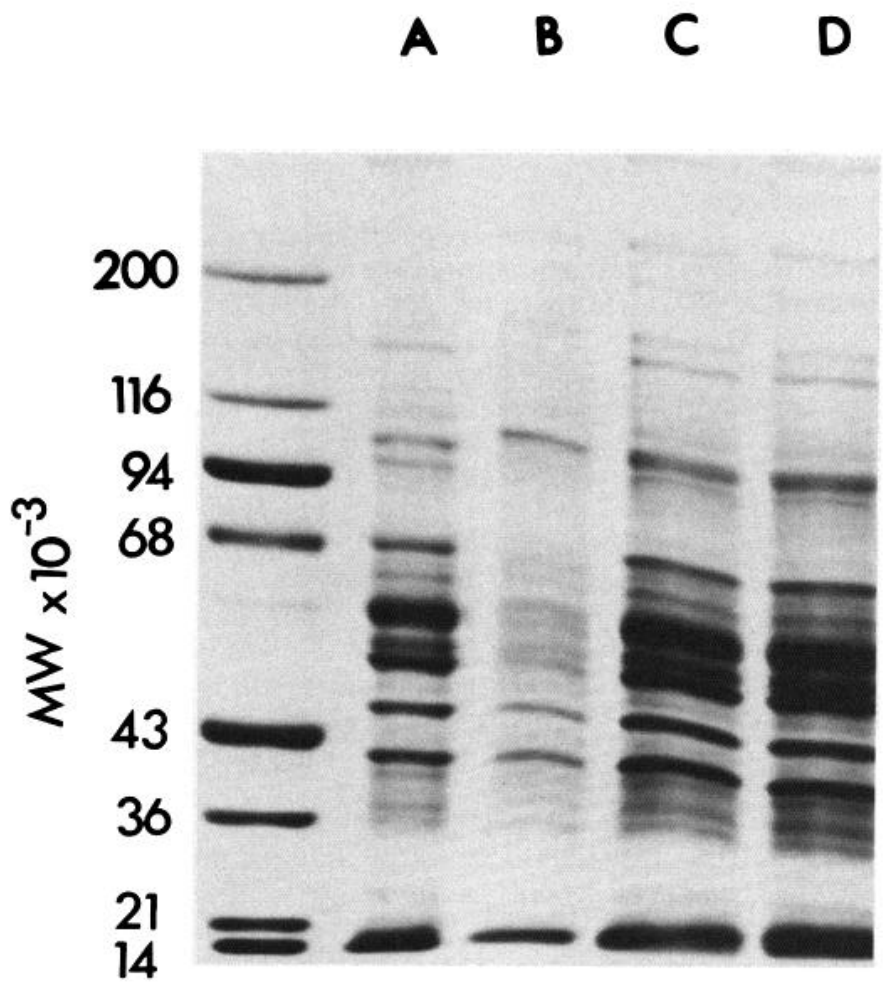

Figure 6. Gradient (7\% to $11 \%$ ) polyacrylamide SDS-gel electrophoresis patterns of proteins from: $(A)$ axoplasm incubated with $\mathrm{Ca}^{2+},(B)$ synaptosome homogenates incubated with $\mathrm{Ca}^{2+},(C)$ equal mixtures of $A$ and $B$, and $(D)$ mixtures of axoplasm and synaptosome homogenates co-incubated with $\mathrm{Ca}^{2+}$. All samples were incubated for $30 \mathrm{~min}\left(10 \mathrm{mM} \mathrm{Ca}^{2+}\right)$ at $23^{\circ} \mathrm{C}$ and the reaction was terminated by the addition of SDS. Molecular weight markers are shown in the left column. Note that the presence of axoplasmic CAP during the incubation revealed no protein substrate in the synaptosomes.

that the synaptosomes do not contain a major endogenous substrate for the CAP.

The data in Figure 6 also argue against an endogenous inhibitor of CAP activity in the synaptosomes. If such an inhibitor was present, then one might have expected the premixed incubate (Fig. 6, column $D$ ) to have failed to degrade the endogenous 200,000-dalton substrate (see Fig. 5, axoplasm) present in the axoplasm component of the sample. The fact that this 200,000 -dalton protein was equally degraded (Fig. 6, columns $C$ and $D$ ) whether or not the synaptosome homogenate was present during the incubation with $\mathrm{Ca}^{2+}$ indicates that the presence of an endogenous inhibitor cannot account for the lack of CAP activity in the synaptosomes. Consistent with this interpretation are the results of similar "mix" experiments using the $\left[{ }^{14} \mathrm{C}\right]$ casein assay, which showed that addition of synaptosome homogenates to axoplasm did not affect the degradation of the casein (i.e., the measured CAP activity) by the axoplasmic CAP (H. C. Pant, P. E. Gallant, R. Gould, and H. Gainer, unpublished data).

\section{Discussion}

The absence of any detectable CAP activity in the synaptosome preparations (Table I) obviously precluded any attempt by us to study whether its $\mathrm{Ca}^{2+}$ dependency was shifted to more physiological levels than that of the CAP activity in the axon. However, the coordinate absence of both endogenous substrate and enzyme specifically in the nerve terminal, together with the appropriate differential time course between neurofilament degradation and CAP inactivation (Fig. 4), could be interpreted as support for the idea of a programed turnover of neurofilaments as they enter the nerve terminals, with a subsequent inactivation of the CAP. Other workers also have noted that CAP is unstable in the presence of $\mathrm{Ca}^{2+}$ and have attributed this inactivation to autolysis (Puca et al., 1977; Gilbert et al., 1975; Truglia and Stracher, 1981; Murachi et al., 1981 a, b). However, even if the above hypothesis is correct, the discrepancy between the high calcium concentrations necessary for axonal CAP activation and its relatively low levels in nerve terminals remains problematic.

In a recent review, Ishiura (1981) points out that this discrepancy is a common one in many systems which contain CAP and that, to date, no factor has been found which could shift the CAP's sensitivity to $\mathrm{Ca}^{2+}$. Similarly, we have tested a variety of substances for their ability to shift the $\mathrm{Ca}^{2+}$ dependency of CAP in axoplasm with no success. These included 1 to $10 \mathrm{~mm}$ adenosine monophosphate, 1 to $10 \mathrm{~mm}$ adenosine diphosphate, 1 to 10 $\mathrm{mm}$ adenosine triphosphate, 1 to $50 \mu \mathrm{M}$ trifluoperazine, 1 to $100 \mu \mathrm{g} / \mathrm{ml}$ of calmodulin, and synaptosomal homogenate (H. C. Pant, P. E. Gallant, R. Gould, and H. Gainer, unpublished data). Another possibility which we considered was whether the localization of the CAP in situ influenced its $\mathrm{Ca}^{2+}$ sensitivity. For example, we observed that the rate of degradation of at least one component of the endogenous $\mathrm{NF}_{200}$ protein substrate was considerably higher than the exogenous casein (Fig. $2 B$ ). One possible explanation for this could be that this $\mathrm{NF}_{200}$ component in our sample was favorably localized near the CAP and, hence, had a lower effective $K_{m}$.

Recently, Morris et al. (1981) showed that it was possible to maintain an intact cytoskeletal network in extruded squid axoplasm that had been extracted in buffers of low chaotropicity and that this network contained CAP activity (i.e., selectively degraded the neurofilament proteins in the presence of $\mathrm{Ca}^{2+}$ ). We have prepared such network preparations using artificial axoplasm buffers (see "Materials and Methods") and have found that the sensitivity of CAP to $\mathrm{Ca}^{2+}$ in this network preparation was identical to that of our standard preparation (shown in Fig. 1). It is known that there are two types of CAPs extractable from various tissues, which have different elution positions in DEAE-cellulose chromatography, one with a high sensitivity $(<40 \mu \mathrm{M})$ and the other with a low sensitivity $(>500 \mu \mathrm{M})$ to $\mathrm{Ca}^{2+}$ (Murachi et al., 1981a, b; Mellgren, 1980). Murachi et al. (1981b) have shown that of 11 tissues studied which had CAP activity, nervous tissue (brain) was the least abundant in the high $\mathrm{Ca}^{2+}$ sensitivity form (referred to by those workers as Calpain I). Although some evidence is available for Calpain I in brain (see Baudry and Lynch, 1980; Baudry et al., 1981), it is unlikely that this is the type of CAP associated with the neurofilaments. In contrast, Calpain II (the low $\mathrm{Ca}^{2+}$ sensitivity form of CAP) was quite abundant in brain tissue (Murachi et al., 1981b) 
and would appear to be the type of CAP found in squid axoplasm (Table I; Fig. 1).

These considerations suggest that axonal CAP does indecd have a high threshold ( $>500 \mu \mathrm{M}$ ) for activation by $\mathrm{Ca}^{2+}$. This would make biological sense in the axon, where the neurofilaments are stable structural components and are degraded only after injury to the nerve when intracellular calcium concentrations could approach extracellular levels (Schlaepfer, 1974; Schlaepfer and Micko, 1978). What then could account for the activation of axonal CAP as it enters the nerve terminals? Two speculative possibilities are: (1) the axonal CAP undergoes a post-translational modification (e.g., via limited proteolysis, phosphorylation, methylation, etc.) in the nerve terminal which shifts its sensitivity to $10^{-6} \mathrm{M}$ calcium levels or (2) the neurofilament. CAP complex is routed through a region in the nerve terminal which contains a high local concentration of calcium. The smooth endoplasmic reticulum (SER) elements found in synaptic endings which sequester calcium (Blaustein et al., 1980) could be involved in the latter mechanism. Indeed, it has been suggested, in view of the structural and functional similarities between nerve terminal SER and muscle sarcoplasmic reticulum, that the nerve terminal SER also may release calcium during depularization in order to influence various cellular activities (McGraw et al., 1980). One of these activities could be to activate CAP and selectively degrade neurofilaments in the nerve terminal. The above two speculations are not mutually exclusive, and further work is necessary to evaluate whether either (or both) of these possible mechanisms is operating in situ.

The above discussion assumed that the absence of CAP activity found in the synaptosomes derived from squid optic lobe was representative of nerve endings in general. However, we should point out that, although the abundant retinal fibers which project to the optic lobe contain CAP (see Table I), we have not yet proven that nerve terminals derived from these specific axons are significantly present in our synaptosome preparations. It is conceivable that the synaptosomes could have been derived from optic lobe neurons which do not contain CAP. We are currently attempting to purify CAP from the giant axon in order to make specific antibodies against this protease. With such antibodies, it should be possible to probe for CAP immunocytochemically in the various regions (e.g., nerve terminals), of the stellate ganglion neurons which give rise to the giant axon.

\section{References}

Anderson, D. R., J. L. Davis, and K. L. Carraway (1977) Calcium-promoted changes of the human erythrocyte membrane. Involvement of spectrin, transglutaminase, and membrane bound protease. J. Biol. Chem. 252: 6617-6623.

Anderton, B. H., C. W. Bell, B. J. Newby, and D. S. Gilbert (1976) Neurofilaments. Biochem. Soc. Trans. 4: 544-547.

Baudry, M., and G. S. Lynch (1980) Regulation of hippocampal glutamate receptors: Evidence for the involvement of a calcium activated protease. Proc. Natl. Acad. Sci. U. S. A. 77: 2298-2302.

Baudry, M., M. C. Bundman, E. R. Smith, and G. S. Lynch (1981) Micromolar calcium stimulates proteolysis and glutanuate binding in rat brain synaptic membranes. Science 212: 937-938.
Bertolini, M. J., D. L. Tankerskey, and D. D. Schroeder (1976) Staining and destaining polyacrylamide gels: A comparison of Coomassie Blue and Fast Green. Anal. Biochem. 71: 6-13.

Blaustein, M. P., R. W. Ratzlaff, and E. S. Schweitzer (1980) Control of intracellular calcium in presynaptic nerve terminals. Fed. Proc. 39: 2790-2795.

Bradford, M. (1976) A rapid and sensitive method for the quantitation of microgram quantities of protein utilizing the principal of protein-dye binding. Anal. Biochem. 72: 248-254.

Dayton, W. R., D. E. Goll, M. G. Zeece, R. M. Robson, and W. J. Reville (1976a) $\mathrm{A} \mathrm{Ca}^{2+}$ activated protease possibly involved in myofibrillar protein turnover. Purification from porcine muscle. Biochemistry 15: 2150-2158.

Dayton, W. R., W. J. Reville, D. E. Goll, and M. G. Storms (1976b) $\mathrm{Ca}^{2+}$ activated protease possibly involved in myofibrillar protein turnover. Partial characterization of purified enzyme. Biochemistry 15: 2159-2167.

Dowdell, M. J., and E. J. Simon (1973) Comparative studies on synaptosomes: Uptake of [N-Me- $\left.{ }^{3} \mathrm{H}\right]$-choline by synaptosomes from squid optic lobes. J. Neurochem. 20: 921-931.

Dowdell, M. J., and V. P. Whittaker (1973) Comparative studies on the preparation of synaptosomes from the head ganglion of the squid, Loligo pealii. J. Physiol. (Lond.) 253: 303-319.

Eagles, P. A. M., D. S. Gilbert, and A. Maggs (1981) The location of phosphorylation sites and calcium dependent proteolytic cleavage sites on the major neurofilament polypeptides from Myxicola infundibulum. Biochem. J. 199: 101111.

Gilbert, D. S. (1975) Axoplasm chemical composition in Myxicola and solubility properties of its structural proteins. J. Physiol. (Lond.) 253: 303-319.

Gilbert, D. S., B. J. Newby, and B. H. Anderton (1975) Neurofilament disguise, destruction and discipline. Nature 256: 586-589.

Goldberg, A. L., and A. C. St. John (1976) Intracellular protein degradation in mammalian and bacterial cells. Annu. Rev. Biochem. 45: 757-803.

Gorovsky, M. A., K. Carlson, and J. L. Rosenbaum (1970) Simple method for quantitative densitometry of polyacrylamide gels using Fast Green. Anal. Biochem. 35: 359-370.

Guroff, G. (1964) A neutral, calcium-activated protease from the soluble fraction of the rat brain. J. Biol. Chem. 239: 149155.

Hamon, M., and S. Bourgoin (1979) Characterization of the $\mathrm{Ca}^{2+}$-induced proteolytic activation of tryptophan hydroxylase from the rat brain stem. J. Neurochem. 32: 1837-1844.

Holzer, H., and P. C. Heinrich (1980) Control of proteolysis. Annu. Rev. Biochem. 49: 63-91.

Huston, R. B., and E. G. Krebs (1968) Activation of skeletal muscle phosphorylase kinase by $\mathrm{Ca}^{2+}$. II. Identification of the kinase activating factor as a proteolytic enzyme. Biochemistry 7: 2116-2121.

Ishiura, S. (1981) Calcium dependent proteolysis in living cells. Life Sci. 29: 1079-1088.

Ishiura, S., H. Murofushi, K. Suzuki, and K. Imahori (1978) Studies of a calcium-activated protease from chicken skeletal muscle. I. Purification and characterization. J. Biochem. (Tokyo) 84: 225-230.

Kameyama, T., and J. D. Etlinger (1979) Calcium-dependent regulation of protein synthesis and degradation on muscle. Nature 279: 344-346.

Lajtha, A., and D. Dunlap (1981) Turnover of protein in the nervous system. Life Sci. 29: 755-767.

Lasek, R. J., and M. M. Black (1977) How do axons stop growing? Some clues from the metabolism of the proteins in the slow component of axonal transport. In Mechanisms, Regulations, and Special Functions of Protein Synthesis in the Brain, E. Roberts, A. Lajtha, and W. H. Gispen, eds., pp. 161-169, Elsevier/North-Holland, New York. 
Lasek, R. J., and P. M. Hoffman (1976) The neuronal cytoskeleton, axonal transport and axonal growth. In Cell Motility, R. Goldman, pp. 1021-1049, Cold Spring Harbor Laboratory, Cold Spring Harbor, NY.

Libby, P., and A. L. Goldberg (1978) Leupeptin, a protease inhibitor, decreases protein degradation in normal and diseased muscles. Science 199: 534-536.

Llinas, R. R., and J. E. Heuser (1977) Depolarization-release coupling systems in neurons. Neurosci. Res. Program Bull. 15: $557-687$.

Lucas, R. C., S. Rosenberg, J. Lawrence, S. Shafig, and A. Stracher (1979) The isolation of a cytoskeleton and a contractile apparatus from human platelets. In Cytoskeleton Structure, Protides of the Biological Fluids, E. Luscher and H. Peeters, eds., Vol. 26, pp. 465-470, Pergamon Press, Oxford.

McGraw, C. F., A. V. Somolyo, and M. P. Blaustein (1980) Probing for calcium at presynaptic terminals. Fed. Proc. 39: 2796-2801.

Mellgren, R. L. (1980) Canine cardiac calcium-dependent proteases: Resolution of two forms with different requirements for calcium. FEBS Lett. 109: 129-133.

Morris, J. R., A. J. Hodges, and R. J. Lasek (1981) The microtubule network in the squid giant axon. Biol. Bull. 161: 308 .

Murachi, T., K. Tanaka, M. Hatanaka, and T. Murakami (1981a) Intracellular $\mathrm{Ca}^{2+}$-dependent protease (calpain) and its high molecular weight endogenous inhibitor (calpastatin). Adv. Enzyme Regul. 19: 407-424.

Murachi, T., M. Hatanaka, Y. Yasumoto, N. Nakayama, and K. Tamaka (1981b) A quantitative distribution study on calpain and calpastatin in rat tissue and cells. Biochem. Int. 2: 651-656.

Neurath, H., and K. A. Walsh (1976) Role of proteolytic enzymes in biological regulation. Proc. Natl. Acad. Sci. U. S. A. 73: $3825-3832$.

Neville, D. (1971) Molecular weight determination of proteindodecyl sulfate complexes by gel electrophoresis in a discontinuous buffer system. J. Biol. Chem. 246: 6328-6334.

Nishizuki, Y., Y. Takai, E. Hashimoto, A. Kishimoto, Y. Kuroda, K. Sakai, and H. Yamamura (1979) Regulation and functional compartment of three multifunctional protein kinase systems. Mol. Cell. Biochem. 23: 153-165.

O'Brien, R. A. D., A. J. C. Ostberg, and . G. Vrbova (1978) Observations on the elimination of polyneuronal innervation in developing mammalian skeletal muscles. J. Physiol. (Lond.) 282: 571-582.

Pant, H. C., and H. Gainer (1980) Properties of calcium-activated protease in squid axoplasm which selectively degrades neurofilament proteins. J. Neurobiol. 11: 1-12.

Pant, H. C., S. Terakawa, and H. Gainer (1979a) A calcium activated protease in squid axoplasm. J. Neurochem. 32: 99102.

Pant, H. C., H. B. Pollard, G. D. Pappas, and H. Gainer (1979b)
Phosphorylation of specific distinct proteins in synaptosomes and axons from squid nervous system. Proc. Natl. Acad. Sci. U. S. A. 76: 6071-6075.

Phillips, D. R., and M. Jakabova (1977) $\mathrm{Ca}^{2+}$ dependent protease in human platelets. J. Biol. Chem. 252: 5602-5605.

Puca, G. A., E. Nola, V. Sica, and F. Breciani (1977) Estrogen binding of proteins of calf uterus. Molecular and functional characterization of the receptor transforming factor: $\mathrm{A} \mathrm{Ca}^{2+}$. activated protease. J. Biol. Chem. 252: 1358-1370.

Reich, E., D. B. Rifkin, and E. Shaw (1975) Proteases and biological control. Cold Spring Harbor Conf. Cell Proliferation 2: 1-102.

Rubinson, K. A., and P. F. Baker (1979) The flow properties of axoplasm in a defined chemical environment: Influence of anions and calcium. Proc. R. Soc. Lond. (Biol.) 205: 323-345.

Schlaepfer, W. W. (1974) Calcium-induced degeneration of axoplasm in isolated segment of rat peripheral nerve. Brain Res. 69: 203-215.

Schlaepfer, W. W., and I. A. Freeman (1980) Calcium-dependent degradation of mammalian neurofilaments by soluble tissue factors(s) from rat spinal cord. Neuroscience 5: 23052314.

Schlaepfer, W. W., and S. Micko (1978) Chemical and structural changes of neurofilaments in transected rat sciatic nerve. J. Cell Biol. 78: 369-378.

Schlaepfer, W. W., U. J. P. Zimmerman, and S. Micko (1981) Neurofilament proteolysis in rat peripheral nerve. Homologous with calcium-activated proteolysis of other tissues. Cell Calcium 2: 235-250.

Stracher, A., E. G. McGowan, and S. S. Shafig (1978) Muscular dystrophy: Inhibition of degeneration in vivo with protease inhibitors. Science 200: 50-51.

Triplett, R. B., J. M. Wingatte, and K. L. Carraway (1972) Calcium effects on erythrocyte membrane proteins. Biochem. Biophys. Res. Commun. 49: 1014-1020.

Truglia, J. A., and A. Stracher (1981) Purification and characterization of a calcium dependent sulfhydryl protease from human platelets. Biochem. Biophys. Res. Commun. 100: 814822.

Umezawa, H., and T. Aoyagi (1977) Activities of proteinase inhibitors of microbial origin. In Proteinases in Mammalian Cells and Tissues, A. J. Barrett, ed., pp. 637-722, Elsevier/ North-Holland, New York.

Vedeckis, W. V., M. R. Freeman, W. T. Schrader, and B. W. O'Malley (1980) Progesterone-binding components of chick oviduct: Partial purification and characterization of a calcium-activated protease which hydrolyzes the progesterone receptor. Biochemistry 19: 335-343.

Wallach, D., P. J. A. Davies, and I. Pastan (1978) Purification of mammalian filamin. J. Biol. Chem. 253: 3328-3335.

Zackroff, R. V., and R. D. Goldman (1980) In vitro reassembly of squid brain intermediate filaments (neurofilaments): $\mathrm{Pu}$ rification by assembly-disassembly. Science 208: 1152-1155. 